\title{
Freud's disciples between biography and autobiography. Towards a collective history of the psychoanalytic movement
}

\section{Summary}

The article explores the auto/biographical narratives devoted to Freud written by his disciples. The author argues that both biography and autobiography were important life-writing genres used by psychoanalysts in the first half of the twentieth century to express their subjective views on the history of the psychoanalytic movement. The chosen biographies of Freud shed light on the close relationship between "subjective" autobiographical discourse (based on self-observation and auto-analysis) and the "objective” role of a biographer. The author argues that the early auto/ biographies of Freud's disciples presented a different history of psychoanalytic knowledge, where the collective thinking and affective relationships are shown to be crucial in the development of the psychoanalytic movement.

\section{Keywords}

psychoanalysis, life-writing, Fritz Wittels, Isidor Sadger, Helene Deutsch

The aim of this article is to examine the early biographies of the Psychoanalytic Movement written by Freud's first disciples. Not only biographies and autobiographies, but also memoirs, diaries, and letters were essential life-writing genres used by psychoanalysts between 1908-1938. As part of everyday writing practices, they functioned as a means of expressing

\footnotetext{
*Contact with author: agnieszka.wieckiewicz@gmail.com; ORCID: 0000-0002-2119-7215.
} 
new theoretical ideas. While Freud's correspondence with Wilhelm Fliess has been generally recognized as a fundamental work for the emergence of psychoanalysis ${ }^{1}$, other life-writing genres, such as biography and autobiography written by Freud and his colleagues have been studied less often. I argue that discussion of these under-explored (auto)biographical works opens up the possibility of introducing a new critical perspective for reading psychoanalytic theory, which is orientated around the blurred borders between autobiography, biography, fiction and history-writing.

Close reading of the life-writing genres used by psychoanalysts enables us to both rethink psychoanalytic theory and to reinterpret the history of the movement inspired by Freud. In this article, I emphasize that by concentrating on biographical and autobiographical texts rather than on works commonly seen as "theoretical" and "scientific" - we are able to disconnect ourselves from the familiar patterns of understanding psychoanalysis. Instead, we can enquire into the affective dynamics within Freud's movement, as well as the role of emotion in knowledge formation ${ }^{2}$. From the very beginning of the Vienna Psychoanalytic Society, Sigmund Freud and his closest disciples sought to create a convincing narrative about the birth and the development of psychoanalysis. While for Freud the correspondence provided fertile ground for the development of his theoretical ideas, his followers often used biographical or autobiographical forms to rethink psychoanalytic theory and to problematize their role in the movement.

Even before An Autobiographical Study ${ }^{3}$ was published in 1925, the founder of psychoanalysis could have read the first biography about himself. Published in 1924, Sigmund Freud. Der Mann, Die Lehre, die Schule ${ }^{4}$ was written by an early member of The Vienna Psychoanalytic Society, Fritz Wittels. Only a few years later Wittels's cousin Isidor Sadger started working on another Freud biography, which was published in 1932 under the title Sigmund Freud. Persönliche Erinnerungen ${ }^{5}$. Both works evoked rather negative reactions in the psychoanalytic movement and were treated as gossipy and unserious ${ }^{6}$. During the Second World War, Helene Deutsch, one of Freud's most intimate colleagues, wrote a short biographical sketch

1 Didier Anzieu, L'auto-analyse de Freud et la découverte de la psychanalyse (Paris: Presses Universitaires de France, 1988).

2 On affective pedagogy - see: Eve Kosofsky Sedgwick, Touching Feeling. Affect, Pedagogy, Performativity (Durham: Duke University Press, 2003).

3 Sigmund Freud, “An Autobiographical Study”, in: The Standard Edition of the Complete Psychological Works of Sigmund Freud, vol. 20, ed. James Strachey (London: The Hogarth Press, 1959), 1-74.

4 Fritz Wittels, Sigmund Freud. Der Mann, die Lehre, die Schule (Leipzig: E.P. Tal, 1924).

5 Isidor Sadger, Recollecting Freud, ed. Alan Dundes (Madison: The University of Wisconsin Press, 2005).

6 Alan Dundes, “Introduction”, in: ibidem, xli-xlii. 
entitled Freud and his Pupils. A Footnote to the History of the Psychoanalytic Movement, which she published in 1940 in The Psychoanalytic Quarterly7. Written shortly after Freud's death in 1939, Deutsch's biographical essay can be seen as an attempt to write an affective history of the psychoanalytic movement. The idea of creating a more emotional biography to reveal the non-linear dynamics of knowledge transmission within the psychoanalytic movement connects the works of life-writing by Wittels, Sadger and Deutsch.

The blurring of genres within biographies and autobiographies written by psychoanalysts was frequent. It is therefore important to enquire into the close relation between biographywriting and autobiography, as well as their orientation towards modernist and experimental literature $^{8}$. Biography-writing can be understood as a practice of transcribing the history of the psychoanalytic knowledge where the role of a biographer becomes a way to tell his or her own story. Thus the biographies of Freud written by his disciples can be also seen as autobiographies of their authors. In this paper, I consider the chosen examples of the psychoanalytic movement's biographies to be its (counter)histories. I thus propose reading them as illustrations of their authors' narrative strategies, which subsequently led to the creation of a more complex and polyphonic image of the movement than Freud wanted to visualize.

\section{Freud and biography. Writing the movement's history}

The first biographical essay devoted to the history of the psychoanalytic movement was written by Freud himself and published in $1914^{9}$. The author of The Interpretation of Dreams, however, never wanted to become a biographer or the subject of any biography. It is interesting to note that Freud's anxiety towards biographers started even before the emergence of psychoanalytic theory. In 1885 he wrote to Martha Bernays, his fiancée at that time: "I have destroyed all my notes of the last fourteen years, as well as letters, scientific extracts, and manuscripts of my works" ${ }^{10}$. In the same letter he adds, "Let the biographer labor and toil, we won't make it too easy for them" ${ }^{11}$. That was not the only time Freud decided to destroy his documents in order to discourage future biographers. In 1938, shortly before his forced

7 Helene Deutsch, “Freud and his Pupils. A Footnote to the History of the Psychoanalytic Movement”, Psychoanalytic Quarterly 9 (1940): 184-194.

8 On psychoanalysis and a modernist literature - see: Max Saunders, Self Impression: Life-Writing, Autobiografiction, and the Forms of Modern Literature (Oxford: Oxford University Press, 2010), 291-336, 438-483.

9 Sigmund Freud, “Zur Geschichte der psychoanalytischen Bewegung”, Jahrbuch für psychoanalytische und psychopathologische Forschung 6 (1914), 1: 207-260.

10 Peter Gay, Freud. A Life for our Time (New York: W.W. Norton \& Company, 2006), xv.

11 Ibidem. 
emigration to England, he threw away his documents and manuscripts, only for them to be salvaged by his daughter Anna.

Freud's views on biography did not change over the years. In his 1910 article on Leonardo da Vinci, he tried to distinguish biographers from psychoanalysts, seeing the latter as someone who aims to write someone else's history. If, as he suggested, biographers "are fixated on their hero in a quite particular way"12, which means that they have a strong affection for a chosen hero, psychoanalysts use Freud's theory in a more objective manner, allowing them to scientifically analyze another person's life story. In Freud's understanding that would be the main difference between a regular biography and a "psychography" ${ }^{13}$. As Peter Gay correctly suggested, the founder of psychoanalysis in general "had little faith in the biographical enterprise" ${ }^{14}$.

Nevertheless, in 1914 Freud wrote the first biography of the movement. His work was addressed particularly at the former analysts Alfred Adler and Carl Gustav Jung as a critique of their "misinterpretations" of psychoanalytic theory. Later, in 1925, Freud decided to rethink the history of the psychoanalytic movement and wrote An Autobiographical Study. By creating the movement's biography, he presented what would come to be considered the "official" image of psychoanalysis, thus countering other possible interpretations emerging within the psychoanalytic society. Freud's (auto)biographic narrative thus functioned as a "stabilizer", which - following Louis Althusser - can be understood as a form of ideology ${ }^{15}$. Freud's History of the Psycho-Analytical Movement not only stabilized the image of movement's evolution but also in a way served to repress other possible versions of its biography. However, in the case of the Vienna Psychoanalytic Society, Freud failed in his aim of putting an end to discussions around the internal conflicts within his circle and determining which theoretical ideas were entitled to be called "psychoanalytic". With his autobiographical texts, Freud had created a narrative which instead of constraining other biographies of the psychoanalytic movement, started to multiply with the irrepressible desire to re-write its history.

\footnotetext{
12 Sigmund Freud, „Leonardo Da Vinci and a Memory of his Childhood”, in: The Standard Edition of the Complete Psychological Works of Sigmund Freud, vol. 11, ed. James Strachey (London: The Hogarth Press, 1957), 57-138.

13 The term was introduced by Isidor Sadger - see: idem, „Von der Pathographie zur Psychographie”, Imago 1 (1912), 2: 158-175.

14 Gay, Freud, XVI.

15 Louis Althusser, „Ideology and ideological state apparatuses”, in: Lenin and Philosophy and Other Essays, transl. Ben Brewster (London: New Left Books, 1971), 123-173.
} 
The psychoanalytic family. Fritz Wittels and Isidor Sadger

Fritz Wittels' biography of Freud was published in 1924. The author began his text with a general history of psychoanalytic thought reconstructed in light of Freud's own scientific development. He mentions Freud's early theoretical ideas and outlines the influence that great scientists and physicians of the latter half of the nineteenth century had on Freud ${ }^{16}$. The second part of Wittels's biography is devoted to the birth of psychoanalysis. Concentrating on The Interpretation of Dreams, he presents the basic concepts of Freud's theory. He does not, however, avoid reading and citing other theorists, even if their ideas stood in opposition to "orthodox" psychoanalysis, as was the case with Wilhelm Stekel or Alfred Adler, who left the Vienna Psychoanalytic Society before 1914.

Freud saw Wittels' biography as a dangerous and unwanted step towards blurring psychoanalytic theory ${ }^{17}$. He believed the author's reflections on the movement's history disrupted the line of thinking about psychoanalysis that he had already established. In On the History of the Psycho-Analytical Movement, Freud emphasized the need to define the boundaries of his theory ${ }^{18}$. After 1914, it was not so easy to call oneself a psychoanalyst. This fear of misinterpreting Freud was expressed by Georg Groddeck in a letter sent to his teacher in 1917. The German physician and psychoanalyst-to-be wrote: "I doubt whether I have the right to call myself a psychoanalyst publicly". Nevertheless he adds: "It is not possible, while advancing such ideas, to use terminology that differs from the one you have developed. It cannot be replaced, and it suits my purpose, too, if the concept of the unconscious is enlarged" ${ }^{19}$. In his biography Wittels addresses the same problem that Groddeck raised, that is: how to use Freud's concepts and categories without reinterpreting them? In Sigmund Freud. Der Mann, die Lehre, die Schule, Wittels opted to search for a deeper understanding of the theories developed by Adler, Stekel and Carl Gustav Jung ${ }^{20}$. He reads psychoanalysis "unorthodoxly", but without attempting to underestimate Freud's creativity.

What is probably the most interesting part of Wittels's biography starts in the final pages of his work as the author's voice starts to be more personal. Writing about his own relationship

\footnotetext{
16 Wittels, Sigmund Freud, 10-25.

17 Wittels mentions this in his autobiography - see: idem, Freud and the Child Women. The Memoirs of Fritz Wittels, ed. Edward Timms (New Haven: Yale University Press, 1996), 120-133.

18 Sigmund Freud, „On the History of the Psycho-Analytical Movement”, in: The Standard Edition of the Complete Psychological Works of Sigmund Freud, vol. 14, ed. James Strachey (London: The Hogarth Press, 1964), $1-66$.

19 Sigmund Freud, Georg Groddeck, Briefwechsel (Frankfurt am Main: Stroemfeld, 2008), 33.

20 Wittels, Sigmund Freud.
} 
to Freud, he concentrates on the affective dynamics of knowledge transmission within the movement. Writing about the way the founder of psychoanalysis treated other analysts especially his colleagues in the Vienna Psychoanalytic Society - Wittels reveals the role of affect and intuition in turning Freud towards certain analysts and away from others. In this context, he argues, the relationships in the psychoanalytic movement consisted of conflicting affects and emotions, such as fascination and disillusionment. He emphasizes that for most young psychoanalysts, Freud was a father-figure. This affective transference resulted not only in love and attachment but also in hatred. He also notes the same about Freud, pointing out that the founder of psychoanalysis initially believed unconditionally in his "chosen" disciples, but in the end his affection always transformed to melancholy after a lost friend, which - as he himself suggested in 1917 - “appears as a neurotic form of mourning” ${ }^{21}$. By writing the biography of Freud, Wittels rejected the established patterns of thinking about the history of psychoanalysis that emerged with On the History of the Psycho-Analytic Movement. What Wittels objected to, in fact, was the idea that the development of psychoanalysis means following the concepts of its founder unconditionally. What is important here is that he saw biography as the most adequate genre for destabilizing the biographical narrative produced by Freud in 1914.

Fritz Wittels was introduced to the Wednesday Psychological Society by his cousin Isidor Sadger, who was one of the first disciples of Freud ${ }^{22}$. He worked on great artists' pathographies at the same time as the founder of psychoanalysis. Sadger also developed a psychoanalytic notion of narcissism, which he introduced to Freud's circle. Although he was one of the most prolific writers and analysts ${ }^{23}$, he was never considered an important figure in The Vienna Psychoanalytic Society. The increasing sense of rejection made Sadger leave Freud's movement in 1933. In 1932, however, he worked on a biography of the founder of psychoanalysis in which he managed to map the affective relations between Freud and his most beloved disciples, such as Carl Gustav Jung and Otto Rank.

At the very beginning of his biographical work, Sadger emphasizes that his perspective is subjective. He does not try to hide behind an image of an objective biographer. In contrast to Wittels, Sadger was not interested in writing a biography of psychoanalytic thought,

${ }^{21}$ Sigmund Freud, „A Seventeenth-Century Demonological Neurosis”, in: The Standard Edition of the Complete Psychological Works of Sigmund Freud, vol. 19, ed. James Strachey (London: The Hogarth Press, 1964), 86.

22 Sadger had known Freud since the late 1890s. - see: Ulrike May, „The Early Relationship between Sigmund Freud and Isidor Sadger: A Dream (1897) and A Letter (1902)”, Psychoanalysis and History 5 (2003), 2: $119-145$.

${ }^{23}$ For list of Sadger's works - see: Elke Mühlleitner, Biographisches Lexikon der Psychoanalyse (Tübingen: Edition Diskord, 1992), 284-285. 
understood in terms of a history of an idea. In his biography, he concentrated on the principal problems within the psychoanalytic society, especially on the contradictory affects upon which Freud's relations with his disciples were built, as well as on the influence of antisemitism and racial stereotypes on the Vienna Psychoanalytic Society. In Recollecting Freud, the author points out that

(...) I need to strongly emphasize: It is not the case, as Freud maintained, that he had always felt like a Jew. He would have liked best to have been a German and was only condemned to go back to despised Judaism very much against his will. (...) So finally, he reminded a Jew (sic!), though not out of loyalty to his hereditary people. Since Christians did not want anything to do with him and his teachings, there was simply no other path open ${ }^{24}$.

In this strong and subjective voice, there is a reference to Freud's scientific split with Jung. Sadger writes: "With Jung, whom he loved, (...) he tried to convince himself (...) that if psychoanalysis could only be Christianized, then its Jewish origin could surely be forgiven" 25 . The author argues that Freud's fascination with Jung was motivated by his aim of freeing psychoanalysis from racist suppositions projected onto Freudians in the first half of the twentieth century. Sadger thus sought to reveal the influence of antisemitism on Freud's life, as well as on the Vienna Psychoanalytic Society more generally.

A close reading of Sadger's work allows us to examine not only the content of his text but also the form, in which the author decided to present his recollections. In the subsequent chapters of his book, Sadger more than once calls Freud a "sadist" as he sought to describe his destructive tendencies towards his disciples ${ }^{26}$. In Sadger text, it is quite evident how his biography of Freud suddenly transforms into a psychography. This particular genre, where the distinction between psychoanalysis and literature becomes blurred, fascinated Sadger throughout his life. Even more interesting is that the author did not manage to hide his own feelings towards Freud behind his biographical language. As Max Saunders suggested in the context of modernist literature and psychoanalysis: "Reading something as 'autobiographical' (...) is different from reading it as 'autobiography'; its autobiographical dimension can be covert, unconscious, or implicit” ${ }^{27}$. Thus, by writing Freud's psychography, Sadger managed to create his own autobiographical portrait.

\footnotetext{
24 Sadger, Recollecting Freud, 99.

25 Ibidem, 79.

26 Ibidem, 23, 31, 35.

27 Saunders, Self Impression, 5.
} 
Recollecting Freud is overflowing not only with disillusionment with Freud as a teacher, but also with a particular sense of melancholy for a lost father-figure. As Eve Kosofsky Sedgwick points out, affects - such as shame or sorrow - can be seen as a basis for identity formation $^{28}$. I would suggest, however, that the development of identity consists of a more complex interactions between different, often contradictory, sensations related to an individual's biography. In the case of Sadger's work, the principal question does not concern the relationship between auto/biography and fiction but the very tension between the desire to write someone else's biography and at the same time to textualize one's own experience of being a psychoanalyst.

\section{Helene Deutsch - a psychological study of the movement}

Helene Deutsch was one of Freuds's closest disciples. Her works devoted to the problem of a female sexuality strongly influenced his understanding of this subject ${ }^{29}$. They also shaped feminist theory of the latter half of the twentieth century ${ }^{30}$. Although Deutsch was a brilliant analyst, she formulated her revelatory ideas in a way that would not openly counter Freud's theory. Her writing strategy clearly shows that she did not want to follow in the footsteps of Adler, Jung or Stekel. Her strategy of remaining within the psychoanalytic movement can be understood as a skillful balancing act between transmitting Freud's theory and developing theoretical ideas that did not always go hand in hand with her teacher's writings.

After emigrating to the USA, Deutsch wrote a short article, Freud and his Pupils. A Footnote to the History of the Psychoanalytic Movement, which was not only provided a commentary to Freud's autobiographical writings but also served as a delayed response to the biographies written by his "rebellious" disciples. At the very beginning of her text, she reminds readers that Freud himself never wanted to become a protagonist of a biography ${ }^{31}$. Whereas this particular genre can present either heroic narrative about the life of its central protagonist or create a distorted image, neither approach, she argued, could generate an objective image of psychoanalysis. Nevertheless, Deutsch's idea was to write a biographical article devoted to psychoanalysis in the form of a short intervention. She aimed to create a history of

\footnotetext{
28 Kosofsky Sedgwick, Touching Feeling, 38-39.

${ }^{29}$ Helene Deutsch, „Psychologie des Weibes in den Funktionen der Fortpflanzung”, Internationale Zeitschrift für Psychoanalyse 11 (1925), 1: 40-53.

30 This applies to Simone de Beauvoir above all. Deutsch's writings, however, were also strongly criticized by American feminist writers, such as Betty Friedan or Élisabeth Badinter - see: Juliet Mitchell, Psychoanalysis and Feminism. Freud, Reich, Laing, and women (New York: Vintage Books, 1975), 313.

31 Deutsch, „Freud and his Pupils”, 184.
} 
psychoanalysis seen as an effect of collective theorizing strategies, rather than as the invention of one man. She describes Freud's relationships with other psychoanalysts, whom she treats more as a group rather than as individuals.

In the first part of her work, Deutsch presents a heroic narrative about the early years of psychoanalysis. She describes the time before the foundation of the Wednesday Psychological Society as a time of a "splendid isolation" 32 . Later she mentions that autobiography in general is closely related to narcissism. She interprets Freud's need to be understood and appreciated by other psychoanalysts as an explication for the "autobiographical" dimension of Freud's writings. Deutsch's biographical sketch also addresses the issue of the analysts' affective relationships with their teacher. She writes

While the less gifted express their ambivalence in a reactively increased dependence and in the overvaluation of the practical value of analysis mentioned above, the more gifted denied this dependence in a more direct but still scientific form and separated themselves from the group in either a noisy and hostile or in more veiled and passive manner. This conjoining of affective and personal with the relational and scientific, this more or less unconscious process of displacement, was the provocation for Freud's often emphasized intolerance ${ }^{33}$.

As Deutsch clearly points out, for the majority of young psychoanalysts, Freud was an idol. They therefore projected onto him the phantasmatic image of a severe father who could never be fully satisfied with his children. Subsequently, she adds, Freud was particularly "severe and relentless" towards "affective motivations concealed behind intellectual and scientific claims, especially when these motives involved his own personality" ${ }^{34}$. The psychoanalyst ends her article as follows:

The loyal band of the chosen few of two generations has undertaken the noble task of preserving the original kernel of Freud's teaching in its best and truly Freudian sense. Sometimes his pupils' adhesion to the orthodoxy of his teaching seems like stubbornness and folly. (...) In defense of those who have disclaimed this immediate task, let it be said that it makes a great difference whether one has grown out of the intimacy with

\footnotetext{
32 Ibidem, 185.

33 Ibidem, 191.

34 Ibidem, 192.
} 
Freud into independence as a loving heir, or whether one owes his independence to an emotional conflict ${ }^{35}$.

Deutsch undoubtedly saw herself as a "loving heir" to Freud, but Fritz Wittels and Isidor Sadger left the psychoanalytic movement with a feeling of being misunderstood and rejected, something that also marked their biographical writings.

The early biographies of Freud written by his disciples displace the heroic image of psychoanalysis created by Freud in 1914 and 1925. Instead of writing a linear history of the birth and a development of the psychoanalytic thought, they present a narrative that reveals not only intellectual, but also affective engagements by analysts working with Freud. Therefore, the biography of psychoanalysis becomes a history of a collective thought, rather than a story about Freud's intellectual achievements. By blurring different life-writing genres, such as biography, autobiography and psychography, Freud's biographers created a counter-history of the psychoanalytic movement, which - immersed within the "autobiographical” - can be seen as their (auto)biography. The chosen biographical works reveal the importance of a sensation (understood as an unorganized affective response to what is being experienced) in knowledge production.

In this article, I have shown that the movement's (auto)biographies are sensible textual reactions to a feeling of a rejection or acceptance by the founder of psychoanalysis. By creating (auto)biographical narratives, Freud's disciples textualized their experience and gave a meaning to something that had seemed completely incomprehensible before.

\section{Bibliography}

Althusser, Louis. „Ideology and ideological state apparatuses”. In: Lenin and Philosophy and Other Essays, transl. Ben Brewster, 123-173. London: New Left Books, 1971.

Anzieu, Didier. L'auto-analyse de Freud et la découverte de la psychanalyse. Paris: Presses Universitaires de France, 1988.

Deutsch, Helene. „Freud and his Pupils. A Footnote to the History of the Psychoanalytic Movement”. Psychoanalytic Quarterly 9 (1940): 184-194.

Deutsch, Helene. „Psychologie des Weibes in den Funktionen der Fortpflanzung”. Internationale Zeitschrift für Psychoanalyse 11 (1925), 1: 40-53.

Dundes, Alan. „Introduction”. In: Isidor Sadger, Recollecting Freud, XLI-XLII. Madison: The University of Wisconsin Press, 2005.

35 Ibidem, 194. 
Freud, Sigmund. „An Autobiographical Study”. In: The Standard Edition of the Complete Psychological Works of Sigmund Freud, ed. James Strachey, 1-74. Vol. 20. London: The Hogarth Press, 1959.

Freud, Sigmund. „Leonardo Da Vinci and a Memory of his Childhood”. In: The Standard Edition of the Complete Psychological Works of Sigmund Freud, ed. James Strachey, 57-138. Vol. 11. London: The Hogarth Press, 1957.

Freud, Sigmund. „On the History of the Psycho-Analytical Movement”. In: The Standard Edition of the Complete Psychological Works of Sigmund Freud, ed. James Strachey, 1-66. Vol. 14. London: The Hogarth Press, 1964.

Freud, Sigmund. „A Seventeenth-Century Demonological Neurosis”. In: The Standard Edition of the Complete Psychological Works of Sigmund Freud, ed. James Strachey, 67-106. Vol. 19. London: The Hogarth Press, 1964.

Freud, Sigmund. „Zur Geschichte der psychoanalytischen Bewegung”. Jahrbuch für psychoanalytische und psychopathologische Forschung 6 (1914), 1: 207-260.

Freud, Sigmund, Georg Groddeck, Briefwechsel. Frankfurt am Main: Stroemfeld, 2008.

Gay, Peter. Freud. A Life for our Time. New York: W.W. Norton \& Company, 2006.

Kosofsky Sedgwick, Eve. Touching Feeling. Affect, Pedagogy, Performativity. Durham: Duke University Press, 2003.

May, Ulrike. „The Early Relationship between Sigmund Freud and Isidor Sadger: A Dream (1897) and A Letter (1902)”. Psychoanalysis and History 5 (2003), 2: 119-145.

Mitchell, Juliet. Psychoanalysis and Feminism. Freud, Reich, Laing, and women. New York: Vintage Books, 1975.

Mühlleitner, Elke. Biographisches Lexikon der Psychoanalyse. Tübingen: Edition Diskord, 1992.

Sadger, Isidor. Recollecting Freud. Madison: The University of Wisconsin Press, 2006.

Sadger, Isidor. „Von der Pathographie zur Psychographie”. Imago 1 (1912), 2: 158-175.

Saunders, Max. Self Impression: Life-Writing, Autobiografiction, and the Forms of Modern Literature. Oxford: Oxford University Press, 2010.

Wittels, Fritz. Freud and the Child Women. The Memoirs of Fritz Wittels, ed. Edward Timms. New Haven, Yale University Press, 1996.

Wittels, Fritz. Sigmund Freud. Der Mann, die Lehre, die Schule. Leipzig: E.P. Tal, 1924. 


\section{Uczniowie Sigmunda Freuda między biografią a autobiografią. W stronę kolektywnej historii ruchu psychoanalitycznego}

\section{Streszczenie}

W artykule podjęto namysł nad biografiami Freuda autorstwa pierwszych freudystów. Autorka dowodzi, że w pierwszych dekadach XX wieku gatunki z zakresu literatury dokumentu osobistego, takie jak autobiografia czy biografia, były chętnie wykorzystywane przez uczniów i uczennice Sigmunda Freuda, którzy wykorzystali je do ukazania subiektywnej wizji narodzin i rozwoju ruchu psychoanalitycznego. Wybrane biografie Freuda zostały odczytane w świetle napięcia między obiektywizującym językiem biografa a dyskursem autobiograficznym. Autorka pokazuje, że wczesne (auto)biografie Freuda napisane przez jego uczniów ujawniają nieznaną historię rozwoju teorii psychoanalitycznej, w której podkreślono wartość kolektywnych strategii teoretyzowania oraz dynamiki afektywnej wpływającej na funkcjonowanie ruchu psychoanalitycznego.

\section{Stowa kluczowe}

psychoanaliza, literatura dokumentu osobistego, Fritz Wittels, Isidor Sadger, Helene Deutsch 


\section{Aa@}

Autobiografia nr 2 (13) 2019 s. 31-39

ISSN 2353-8694

DOI: 10.18276/au.2019.2.13-03

\section{Psychoanaliza i autobiografia - trzy hasła do słownika terminów autobiograficznych}

\section{Streszczenie}

Artykuł przedstawia trzy główne rodzaje związków psychoanalizy i autobiografii. Psychoanaliza zdefiniowana zostaje jako praktyka autobiograficzna, która stała się nauką. Autobiografia to także najważniejsza psychoanalityczna technika terapeutyczna. W świetle teorii Freuda można ją również rozumieć w kategoriach wspomnienia pokrywczego.

Słowa kluczowe

psychoanaliza, autobiografia, wspomnienia pokrywcze

\section{Autobiografia jako teoria}

Psychoanalizę określić można jako praktykę autobiograficzną, która stała się teorią. Jak udowodnił Didier Anzieu ${ }^{1}$, to przedsięwzięta przez Freuda w latach 1895-1902 autoanaliza dostarczyła kluczowych koncepcji teoretycznych, które złożyły się na psychoanalityczną wiedzę o podmiocie. Autor Objaśniania marzeń sennych, dzieła pisanego bezpośrednio po śmierci ojca i pod wieloma względami autobiograficznego - to przede wszystkim ten tekst,

* Kontakt z autorką: lena.magnone@nyu.edu; ORCID: 0000-0003-3008-0825.

1 Didier Anzieu, L'auto-analyse de Freud et la découverte de la psychanalyse (Paris: PUF, 1975). 